\title{
ДОСЛІДЖЕННЯ ЕЛЕМЕНТНОГО СКЛАДУ ГРУШІ ЗВИЧАЙНОЇ ЛИСТЯ СОРТУ НОЯБРСЬКА
}

Вступ. Мінеральні елементи є кофракторами фрерментів, складовими частинами вітамінів, гормонів, усіх клітин і тканин організму, вони необхідні для його нормальної життєдіяльності: підтримки гомеостазу, перебігу біохімічних, фрерментативних, пластичних, гормональних, регуляторних та обмінних процесів, є обов'язковою і незамінною частиною раціону харчування. Їх дефріцит, надлишок чи дисбаланс в організмі може спричинити певні захворювання, синдроми, порушення або патологічні стани.

Мета дослідження - вивчити якісний склад та кількісний вміст мінеральних елементів у груші звичайної листі сорту Ноябрська.

Методи дослідження. Об'єктом дослідження було груші звичайної листя сорту Ноябрська, заготовлене в Івано-Франківській області в серпні 2018 р. Груша звичайна даного сорту широко культивується на території України у приватних і фрермерських господарствах, особливо в західних регіонах та Придністров'ї. Елементний склад груші звичайної листя сорту Ноябрська визначали методом атомно-абсорбційної спектрометрії на базі відділу аналітичної хімії ДНУ НТК “нститут монокристалів" НАН України.

Результати й обговорення. Одержані результати проведеного експериментального дослідження свідчать про наявність у груші звичайної листі сорту Ноябрська 19 мінеральних елементів. У найбільшій кількості в сировині накопичувалися К (2185 мг/100 2), Са (1140 мг/100 2), Mg (380 м2/100 2), P (85 мг/100 г), Si (76 мг/100 2) і Al (62 мг/100 2), у найменшій - Cu (0,23 мг/100 2), Ni (0,11 мг/100 г) ma Mo (0,047 мг/100 г). Вміст важких металів перебував у межах допустимих концентрацій.

Висновки. Методом атомно-абсорбційної спектрометрії у груші звичайної листі сорту Ноябрська ідентияріковано та визначено кількісний вміст 19 мінеральних елементів. Одержані експериментальні дані буде використано в подальшій роботі при прогнозуванні фрармакологічної активності досліджуваної сировини, лікарських засобів на її основі, а також з метою стандартизації та розробки методів контролю якості сировини.

КЛЮЧОВІ СЛОВА: груша звичайна; елементний склад; атомно-абсорбційна спектрометрія.

ВСТУП. Мінеральні елементи є кофракторами ферментів, складовими частинами вітамінів, гормонів, усіх клітин і тканин організму, вони необхідні для його нормальної життєдіяльності: підтримки гомеостазу, перебігу біохімічних, фрерментативних, пластичних, гормональних, регуляторних та обмінних процесів, беруть участь у кровотворенні, утворенні секретів травних залоз, впливають на клітинні мембрани, рецептори і білки-переносники [1-3].

Так, наприклад, калій забезпечує підтримку постійного складу клітинної та міжклітинної рідин, осмотичного тиску, водно-сольового балансу, кислотно-лужної рівноваги, нервово-м'язової збудливості й провідності, бере участь у функціонуванні нервової тканини, підтримці електричної активності мозку, скороченні скелетних і (с) В. О. Пінкевич, О. М. Новосел, 2018. серцевого м'язів, забезпеченні видільної фрункції нирок, регулює активність таких фрерментів, як $\mathrm{K}^{+}$-АТФ-аза, піруваторосорокіназа, ацетилкіназа, $€$ каталізатором при обміні вуглеводів і білків, виступає антагоністом натрію в багатьох фрізіологічних процесах [2, 3].

Кальцій - основа кісткової тканини, забезпечує міцність нігтів та зубів. У вигляді катіона входить до складу плазми крові, тканинних рідин, бере участь у регуляції внутрішньоклітинних процесів, проникності клітинних мембран, серцевих скорочень, згортання крові, зменшує проникність стінок судин, впливає на фрункцію ендокринних залоз [2-4].

Силіцій належить до есенціальних елементів. Він забезпечує нормальний розвиток і фрункціонування сполучної та епітеліальної тканин, впливає на обмін ліпідів [2-4]. 
Алюміній входить до складу багатьох біомолекул, бере участь в утворенні фоосратних і білкових комплексів, процесах регенерації кісткової, сполучної та епітеліальної тканин, впливає на фрункцію прищитоподібних залоз, травних орерментів [3, 4].

Мінеральні речовини $€$ обов'язковою і незамінною частиною раціону харчування, їх основними джерелами для людини є рослинна, тваринна їжа та вода $[1,2,4]$. Дефріцит, надлишок або дисбаланс хімічних елементів в організмі може спричинити певні захворювання, синдроми, порушення або патологічні стани [2, 4]. Тому пошук нових рослинних джерел макро- та мікроелементів $€$ актуальним.

Мета дослідження - визначити якісний склад та кількісний вміст мінеральних елементів у груші звичайної листі сорту Ноябрська.

МЕТОДИ ДОСЛІДЖЕННЯ. Об'єкТОМ дослідження було груші звичайної листя сорту Ноябрська. Даний сорт вивела К. К. Душутіна в Молдавському НДІ садівництва, виноградарства і виноробства. В Україні він широко культивується у приватних і фермерських господарствах, особливо в західних регіонах та Придністров"ї [5]. Сировину заготовляли в Івано-Франківській області в серпні 2018 р.

Елементний склад груші звичайної листя сорту Ноябрська визначали методом атомно-абсорбційної спектрометрії на базі відділу аналітичної хімії ДНУ НТК "Інститут монокристалів" НАН України за такою методикою. Сировину обвуглювали в муфрельній печі при темпе- ратурі, не більшій $500{ }^{\circ} \mathrm{C}$, із попередньою обробкою проб кислотою сульфатною розведеною. Проби випаровували з кратерів грасрітових електродів у розряді дуги змінного струму. Як джерело збудження спектрів використовували IBC-28. Одержували і реєстрували спектри на фоотопластинках за допомогою спектрографра ДФС-8 із трилінзовою системою освітлення щілини та дифракційною решіткою 600 штр/мм. Інтенсивність ліній у спектрах вимірювали із застосуванням мікросоотометра МФ-1.

При проведенні експерименту дотримувалися таких умов реєстрації спектрів: сила дуги змінного струму - 16 А, частота підпалювальних імпульсів - 100 розрядів за секунду; аналітичний проміжок - 2 мм; експозиція - 60 с; ширина щілини спектрограсра-0,015 мм; ділянка реєстрації ліній спектрів - 230-330 нм. Проявляли, висушували фотопластинки, фоотометрували лінії (в нм) спектрів проб, градуювальних зразків, а також фон біля них. Потім будували градуювальний графрік у координатах: середнє значення різниці почорніння лінії та фону - логарифм вмісту елемента в градуювальних зразках, за яким знаходили відсотковий вміст елемента в золі та розраховували його кількісний вміст у досліджуваній сировині [6-8].

РЕЗУЛЬТАТИЙ ОБГОВОРЕННЯ. РеЗУЛЬТаТИ елементного аналізу груші звичайної листя сорту Ноябрська наведено в таблиці.

Як видно з таблиці, методом атомно-абсорбційної спектрометрії в груші звичайної листі сорту Ноябрська встановлено наявність та ви-

Таблиця - Елементний склад груші звичайної листя сорту Ноябрська

\begin{tabular}{|c|c|c|c|}
\hline № $3 / \Pi$ & Символ елемента & Назва елемента & Вміст елемента, мг/100 г \\
\hline \multicolumn{4}{|c|}{ Макроелементи } \\
\hline 1 & $\mathrm{~K}$ & Калій & 2185 \\
\hline 2 & $\mathrm{Ca}$ & Кальцій & 1140 \\
\hline 3 & $\mathrm{Mg}$ & Магній & 380 \\
\hline 4 & $\mathrm{P}$ & Фоссрор & 85 \\
\hline 5 & $\mathrm{Na}$ & Натрій & 47 \\
\hline \multicolumn{4}{|c|}{ Мікроелементи } \\
\hline 6 & Si & Силіцій & 76 \\
\hline 7 & $\mathrm{Al}$ & Алюміній & 62 \\
\hline 8 & $\mathrm{Fe}$ & Ферум & 47 \\
\hline 9 & $\mathrm{Mn}$ & Манган & 17 \\
\hline 10 & $\mathrm{Zn}$ & Цинк & 14 \\
\hline 11 & $\mathrm{Sr}$ & Стронцій & 6,6 \\
\hline 12 & $\mathrm{Cu}$ & Купрум & 0,23 \\
\hline 13 & Mo & Молібден & 0,047 \\
\hline 14 & $\mathrm{~Pb}$ & Плюмбум & $<0,03$ \\
\hline 15 & $\mathrm{Cd}$ & Кадмій & $<0,01$ \\
\hline \multicolumn{4}{|c|}{ Ультрамікроелементи } \\
\hline 16 & $\mathrm{Ni}$ & Нікол & 0,11 \\
\hline 17 & Co & Кобальт & $<0,03$ \\
\hline 18 & As & Арсен & $<0,01$ \\
\hline 19 & $\mathrm{Hg}$ & Меркурій & $<0,01$ \\
\hline
\end{tabular}


значено кількісний вміст 19 елементів. Серед макроелементів за кількістю домінували калій і кальцій (2185 та 1140 мг/100 г відповідно), серед мікроелементів - силіцій і алюміній (76 та 62 мг/100 г відповідно). У найменшій кількості в досліджуваній сировині накопичувалися купрум, нікол і молібден $(0,23,0,11$ та 0,047 мг/100 г відповідно).

Результати елементного аналізу показали, що вміст важких металів перебував у межах допустимих концентрацій. Це відповідає вимогам до сировини та харчових продуктів.

ВИСНОВКИ. 1. Уперше досліджено елементний склад груші звичайної листя сорту Ноябрська.

\section{СПИСОК ЛІТЕРАТУРИ}

1. Титаренко А. В. Вплив вітамінів та мінералів на організм людини / А. В. Титаренко, Е.О.Гришина // Наукові записки КНТУ : зб. наук. праць. - Кіровоград : КНТУ, 2011. - Вип. 11, ч. 3. - С. 240-246.

2. Лифрляндский В. Г. Витамины и минералы / В. Г. Лифрляндский. - М. : ОЛМА Медиа Групп, 2010. $640 \mathrm{c}$

3. Макро- та мікроелементи (обмін, патологія та методи визначення) : монографрія / [М.В.Погорєлов, В. І. Бумейстер, Г. Ф. Ткач та ін.]. - Суми : Вид-во СумДУ, 2010. - 147 с.

4. Скальный А. В. Биоэлементы в медицине / А. В. Скальный, И. А. Рудаков. - М. : Издательский дом Оникс 21 век ; Мир, 2004. - 272 с.

\section{REFERENCES}

1. Tytarenko, A.V., \& Hryshyna, E.O. (2011). Vplyv vitaminiv ta mineraliv na orhanizm liudyny [Influence of vitamins and minerals on the human body]. Naukovi zapysky KNTU - Scientific Notes of KNTU, 11 (3), 240246 [in Ukrainian].

2. Liflyandskiy, V.G. (2010). Vitaminy i mineraly [Vitamins and minerals]. Moscow: OLMA Media Grupp [in Russian].

3. Pohorielov, M.V., Bumeister,V.I., \& Tkach H.F. (2010). Makro- ta mikroelementy (obmin, patolohiia ta metody vyznachennia): monohr. [Macro- and microelements (metabolism, pathology and determination methods): a monograph]. Sumy: Vyd-vo SumDU [in Ukrainian].

4. Skalnyy, A.V., \& Rudakov, I.A. (2004). Bioelementy $v$ meditsine [Bioelements in medicine]. Moscow: Oniks 21 vek; Mir [in Russian].
2. У досліджуваній сировині методом атомно-абсорбційної спектрометрії ідентисріковано та встановлено вміст 19 мінеральних елементів. У найбільшій кількості в груші звичайної листі сорту Ноябрська накопичувалися калій (2185 мг/100 г), кальцій (1140 мг/100 г), магній (380 мг/100 г), фросфрор (85 мг/100 г), силіцій (76 мг/100 г) та алюміній (62 мг/100 г), у найменшій - купрум (0,23 мг/100 г), нікол (0,11 мг/100 г) та молібден (0,047 мг/100 г).

3. Одержані експериментальні дані буде використано в подальшій роботі при прогнозуванні фрармакологічної активності груші звичайної листя сорту Ноябрська, лікарських засобів на її основі, а також з метою стандартизації та розробки методів контролю якості досліджуваної сировини.

5. Матвієнко М. В. Груша в Україні / М. В. Матвієнко, Р. Д. Бабіна, П. В. Кондратенко. -К., 2006. - 320 с.

6. Бурда Н. Є. Вивчення елементного складу грибів кордіцепс, шиїтаке, рейши та майтаке / Н. Є. Бурда, І. О. Журавель // Зб. наук. праць співроб. НМАПО імені П. Л. Шупика. - 2016. - Вип. 26. - С. 308-312.

7. Федосов А. І. Вивчення елементного складу артишоку суцвіть та часнику цибулин / А. І. Федосов, В. С. Кисличенко // Фітотерапія. Часопис. - 2017. № 3. - C. 52-55.

8. Шиморова Ю. Є. Мінеральний склад коренеплодів та плодів пастернаку посівного (Pastinaca sativa L.) сорту Петрик / Ю. Є. Шиморова, В. С. Кисличенко, В. Ю. Кузнєцова // Мед. та клініч. хімія. 2017. - 19, № 2 (71). - С. 101-104.

5. Matviienko, M.V., Babina R.D., \& Kondratenko, P.V. (2006). Hrusha v Ukraini [Pear in Ukraine]. Kyiv [in Ukrainian].

6. Burda, N.Ye., \& Zhuravel, I.O. (2016). Vyvchennia elementnoho skladu hrybiv korditseps, shyitake, reishy ta maitake [The study of element composition of Cordyceps, Shiitake, Reishi and Maitake]. Zbirnyk naukovykh prats spivrobitnykiv NMAPO imeni P.L. Shupyka - Collection of Scientific Works of Staff Member of P.L. Shupyk NMAPE, 26, 308-312 [in Ukrainian].

7. Fedosov, A.I., \& Kyslychenko, V.S. (2017). Vyvchennia elementnoho skladu artyshoku sutsvit ta chasnyku tsybulyn [The study of element composition of artichoke inflorescences and garlic bulbs]. Fitoterapiia. Chasopys - Phytotherapy. Journal, 3, 52-55 [in Ukrainian]. 
8. Shymorova, Yu.Ye., Kyslychenko, V.S., \& Kuznetsova, V.Yu. (2017). Mineralnyi sklad koreneplodiv ta plodiv pasternaku posivnoho (Pastinaca sativa L.) sortu
Petryk [Mineral composition of parsnip (Pastinaca sativa L.) roots and fruits Petrik variety]. Medychna ta klinichna khimiia - Medical and Clinical Chemistry, 19 (2), 101-104 [in Ukrainian].

В. А. Пинкевич, Е. Н. Новосел

\section{ИССЛЕДОВАНИЕ ЭЛЕМЕНТНОГО СОСТАВА ГРУШИ ОБЫКНОВЕННОЙ ЛИСТЬЕВ СОРТА НОЯБРЬСКАЯ}

\section{Резюме}

Вступление. Минеральные элементы являются кофракторами фрерментов, составными частями витаминов, гормонов, всех клеток и тканей организма, они необходимы для его нормальной жизнедеятельности: поддержания гомеостаза, протекания биохимических, фрерментативных, пластических, гормональных, регуляторных и обменных процессов, являются обязательной и незаменимой частью рациона питания. Их дефицит, избыток или дисбаланс в организме может вызвать определенные заболевания, синдромы, нарушения или патологические состояния.

Цель исследования - изучить качественный состав и количественное содержание минеральных элементов в груши обыкновенной листьях сорта Ноябрьская.

Методы исследования. Объектом исследования были груши обыкновенной листья сорта Ноябрьская, заготовленные в Ивано-Франковской области в августе 2018 г. Груша обыкновенная данного сорта широко культивируется на территории Украины в частных и фрермерских хозяйствах, особенно в западных регионах и Приднестровье. Элементный состав груши обыкновенной листьев сорта Ноябрьская определяли методом атомно-абсорбционной спектрометрии на базе отдела аналитической химии ГНУ НТК "Институт монокристаллов" НАН Украины.

Результаты и обсуждение. Полученные результаты проведенного экспериментального исследования свидетельствуют о наличии в груши обыкновенной листьях сорта Ноябрьская 19 минеральных элементов. В нашбольшем количестве в сырье накапливались К (2185 мг/100 г), Са (1140 мг/100 г), Mg (380 мг/100 2), P (85 мг/100 2), Si (76 мг/100 2) и Al (62 мг/100 2), в наименьшем - Cu (0,23 мг/100 2), Ni (0,11 мг/100 г) и Мо (0,047 мг/100 2). Содержание тяжелых металлов находилось в пределах допустимых концентраций.

Выводы. Методом атомно-абсорбционной спектрометрии в груши обыкновенной листьях сорта Ноябрьская идентифицировано и определено количественное содержание 19 минеральных элементов. Полученные экспериментальные данные будут использованы в дальнейшей работе при прогнозировании фрармакологической активности исследуемого сырья, лекарственных средств на его основе, а также с целью стандартизации и разработки методов контроля качества сырья. метрия.

КЛЮЧЕВЫЕ СЛОВА: груша обыкновенная; элементный состав; атомно-абсорбционная спектро-

V. O. Pinkevych, O. M. Novosel NATIONAL UNIVERSITY OF PHARMACY, KHARKIV

\section{THE STUDY OF ELEMENT COMPOSITION OF PEAR LEAVES OF NOIABRSKA CULTIVAR}

\section{Summary}

Introduction. Mineral elements are enzyme cofactors, constituents of vitamins, hormones, all body cells and tissues, they are essential for its normal metabolism: homeostasis support, progress of biochemical, enzymatic, 
plastic, hormonal, regulatory and metabolic processes, being a necessary and vital part of human diet. Their deficiency, excess or imbalance in the body may cause certain diseases, syndromes, disorders or pathological states.

The aim of the study - research on the qualitative composition and quantitative content of mineral elements in pear leaves of Noiabrska cultivar.

Research Methods. The object of the study were pear leaves of Noiabrska cultivar, collected in Ivano-Frankivsk region in August 2018. Pears of this cultivar are widely cultivated on the territory of Ukraine in private households or farms, especially in Western and Transdniester regions. The element composition of pear leaves of Noiabrska cultivar was studied using atomic-absorption spectrometry at the department of analytical chemistry of the State Scientific Institution "Institute for Single Crystals" of National Academy of Sciences of Ukraine.

Results and Discussion. The obtained results of experimental research carried out show the presence of 19 mineral elements in pear leaves of Noiabrska cultivar. K (2185 mg/100 g), Ca (1140 mg/100 g), Mg (380 mg/100 g), $P(85 \mathrm{mg} / 100 \mathrm{~g})$, Si (76 mg/100 g) and Al $(62 \mathrm{mg} / 100 \mathrm{~g})$ were accumulated in the highest amount in the plant material, while Cu (0.23 mg/100 g), Ni $(0.11 \mathrm{mg} / 100 \mathrm{~g})$ and $\mathrm{Mo}(0.047 \mathrm{mg} / 100 \mathrm{~g})$ - in the lowest. The content of heavy metals was within the limits of permissible concentration.

Conclusions. 19 mineral elements were identified in pear leaves of Noiabrska cultivar, and their content was determined by the means of atomic-absorption spectrometry. The received experimental data will be used in further work at predictive modeling of pharmacological activity of the plant material studied, medicinal agents on its basis, as well as at standardization and development of quality control methods for the plant material.

KEY WORDS: Pyrus communis L.; element composition; atomic absorption spectrometry.

Отримано 30.10 .18

Адреса для листування: О. М. Новосел, Національний фрармацевтичний університет, вул. Валентинівська, 4, Харків, 61118, Україна, e-mail: lenanovosel1@ukr.net. 